\title{
LANDSCAPE CHANGE WITH THE TRANSPOSITION OF THE SÃO FRANCISCO RIVER, IN THE DOMAIN CAATINGA, PERNAMBUCO
}

\author{
Lorena de Moura Melo ${ }^{1 *}$, Mayara Maria de Lima Pessoa ${ }^{2}$, Emanuel Araújo Silva ${ }^{3}$, Lúcia de Fatima de Carvalho \\ Chaves $^{4}$

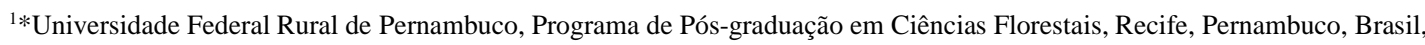 \\ lorem.moura@gmail.com \\ ${ }^{2}$ Instituto Federal de educação, ciência e tecnologia de Minas Gerais - Campus São João Evangelista, professora do ensino técnico e superior, \\ São João Evangelista, Minas Gerais, Brasil - mayara.pessoa@ifmg.edu.br \\ ${ }^{3}$ Universidade Federal Rural de Pernambuco, Departamento de Ciência Florestal, Recife, Pernambuco, Brasil - emanuel.ufrpe@ gmail.com \\ ${ }^{4}$ Universidade Federal Rural de Pernambuco, Departamento de Ciência Florestal, Recife, Pernambuco, Brasil - lucia.chaves@ ufrpe.br
}

Received for publication: 18/02/2020 - Accepted for publication: 12/11/2020

\begin{abstract}
Resumo
Mudanças na paisagem com a transposição do Rio São Francisco, no Domínio Caatinga, Pernambuco. O objetivo deste trabalho foi avaliar a dinâmica de mudança do uso da terra e da cobertura florestal, bem como a estrutura da paisagem, da Área Diretamente Afetada pelo Projeto de Integração do Rio São Francisco com as Bacias Hidrográficas do Nordeste Setentrional, a partir da porção do Eixo Leste, situado no Estado de Pernambuco, Brasil, durante um período de 20 anos. Para tanto, foram utilizadas imagens TM/Landsat 5 e OLI/Landsat 8, referentes aos anos de 1998, 2008 e 2018, período anterior, durante e posterior à transposição, respectivamente. As classes de uso e cobertura da terra usadas nesta análise foram savana-estépica, savanaestépica ciliar, área antropizada e/ou descoberta, recursos hídricos e área agrícola. O processamento e classificação das imagens foram executados no programa QGIS. Para a quantificação das classes de uso, foram feitas aplicações de operações matemáticas do SIG. Também foram realizados estudos relacionados à estrutura da paisagem, por meio do uso de diferentes tipos de métricas, processadas na extensão Patch Analyst do Programa ArcGIS 10.5. Como resultado da análise dos 20 anos, obteve-se que a cobertura vegetal de savanaestépica apresentou uma redução $13,86 \%$. No entanto, ocorreram adições nas áreas de savana-estépica ciliar, recursos hídricos, área agrícola e área antropizada em 1,93\%, $0,11 \%, 0,31 \%$ e $11,51 \%$, respectivamente. Além disso, houve um aumento da fragmentação florestal, o que corroborou com os resultados referentes às métricas de área central, que demonstram que houve uma redução do tamanho dos fragmentos e uma tendência de perda das áreas centrais, devido ao efeito de borda.

Palavras-chave: geotecnologias, savana-estépica, uso da terra, métricas da paisagem.
\end{abstract}

\begin{abstract}
Landscape change with the transposition of the São Francisco River, in the Domain Caatinga, Pernambuco.The objective of this study was to evaluate the dynamics of land use and cover and the landscape structure, as well as the landscape structure, of the Directly Affected Area by Integration Project of the São Francisco River with the Northeastern Hydrographic Basins, from the East Axis portion located in the State of Pernambuco, Brazil. For this purpose, TM / Landsat 5 and OLI / Landsat 8 images were used, referring to the years 1998, 2008 and 2018, periods before, during and after the transposition, respectively. The land use and land cover classes used in this analysis were savanna-steppe, savanna-steppe, anthropized and / or uncovered area, water resources and agricultural area. Image processing and classification were performed using the QGIS software. Also, studies related to the landscape structure were carried out, using different types of metrics, processed in the Patch Analyst tool, an extension of ArcGIS 10.5. As a result of the analysis of the 20 years, it was obtained that the savanna-steppe vegetation cover showed a $13.86 \%$ reduction. However, there were additions in the areas of ciliary savanna, water resources, agricultural area and anthropized area in $1.93 \%, 0.11 \%, 0.31 \%$ and $11.51 \%$, respectively. Furthermore, there was an increase in forest fragmentation, which corroborated with the results regarding for the core area metrics, which show that there has been a reduction in the size of the fragments and a trend towards the loss of the core areas, due to the edge effect.

Keywords: geotechnologies, savanna-steppe, land use, landscape metrics.
\end{abstract}

\section{INTRODUCTION}

As a result of anthropic and/or natural interventions in landscapes, as they acquire heterogeneous spatial conformations, characterized by a mosaic of spots that differ in size, shape, content and history (WU, 2013). As a way of monitoring these changes in the landscape, geotechnologies are used as a means of understanding the fragilities of forest fragments and their consequences for the maintenance of biodiversity, also serving as a basis for studies related to the influence of the landscape pattern in the fire regime region (LARIS et al., 2018). Through combinations of image classification techniques and metric indexes of the landscape, it is possible to evaluate the temporal and spatial evolution of forest fragmentation. (SANTOS et al., 2016).

The Brazilian semi-arid region is a world example of an area with intense changes in its landscapes, requiring constant orbital monitoring of its natural resources. This region occupies $11 \%$ of the Brazilian territory

FLORESTA, Curitiba, PR, v. 51, n. 3, p. 648-657, jul/set 2021.

Melo, L. M. et.al.

ISSN eletrônico 1982-4688

DOI: $10.5380 /$ rf.v51 i3. 71785 
$(844,453 \mathrm{~km} 2)$, characterized by having a floristic diversity that includes about 3,150 species of plants and covering nine biogeographic sub-regions, which result from the heterogeneity of environmental conditions, such as temperature, precipitation and altitude (QUEIROZ et al., 2017; SILVA; SOUZA, 2018). It is one of the regions of the world that presents high ecological sensitivity to climatic variability (SEDDON et al., 2016), with only $9.36 \%$ of its protected areas $(77537,64 \mathrm{~km} 2$ ), corresponding to 208 Conservation Units (UCs) (UNCT, 2020).

Among the current socioeconomic activities that have generated controversy in relation to the conservation of the Caatinga domain, it is the Project for the Integration of the São Francisco River with the Hydrographic Basins of the Northern Northeast (PISF), implemented in the states of Pernambuco (PE), Ceará $(\mathrm{CE})$, Paraíba $(\mathrm{PB})$ and Rio Grande do Norte $(\mathrm{RN})$. The objective of the project was to distribute a percentage of $3.5 \%$ of the waters of the São Francisco River to basins in the semi-arid Northeast region, through two waterconducting channels with a total length of $720 \mathrm{~km}$, known as Northern Axis and Eastern Axis (BRASIL, 2004). The works of the referred project had great proportions and lasted for a long period (they started in 2007 and they were completed in 2017, in the Eastern Axis, and in 2020, in the Northern Axis).

Therefore, there is a need for a temporal analysis of the area, in order to diagnose the possible interactions that PISF may have caused in the landscapes. Given the context presented, this paper aims to answer the following question: Did the transposition of the São Francisco River influence the dynamics of land use and cover in the Eastern Axis? As a main hypothesis, with the construction of the transposition, there was a decrease in forest cover, as well as an increase in exposed soil sites.

Therefore, the objective of this study was to evaluate the dynamics of changes in land use and forest cover, as well as the landscape structure of the Directly Affected Area (DAA) by the São Francisco River Integration Project with the Hydrographic Basins of the Northern Northeast, from the portion of the Eastern Axis located in the State of Pernambuco, Brazil, for a period of 20 years.

\section{METHODS AND MATERIALS}

\section{Location of the study area and general environmental characteristics}

The present study was carried out in the Directly Affected Area (DAA) by the Project for the Integration of the São Francisco River with the Hydrographic Basins of the Northern Northeast (PISF), of the portion of the Eastern Axis, in Pernambuco. The DAA is defined as a strip along the structures of the Project, $5.0 \mathrm{~km}$ wide on each side (BRASIL, 2004) (Figure 1).

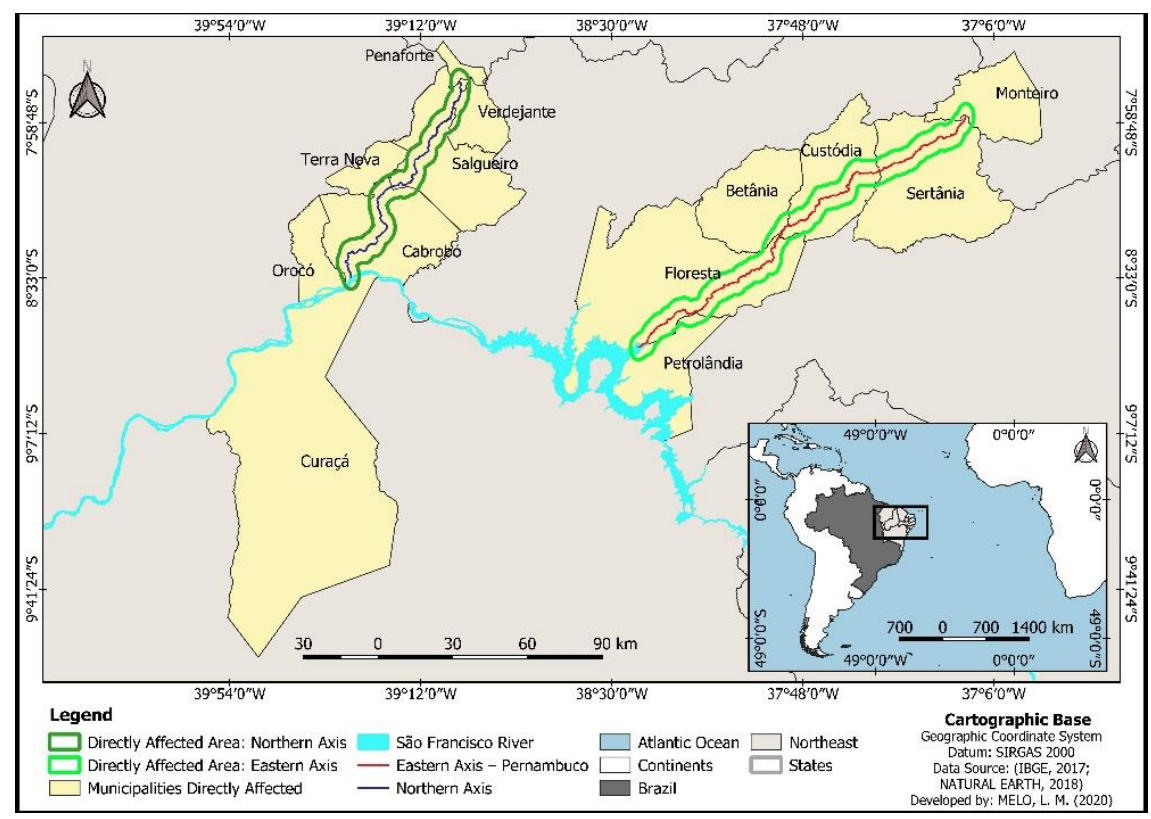

Figure 1. Location map of the Directly Affected Areas by the works of the São Francisco River Integration Project, created from the Northern and Eastern Axes in the State of Pernambuco.

Figura 1. Mapa de localização das Áreas Diretamente Afetadas pelas obras do Projeto de Integração do Rio São Francisco, criadas a partir dos Eixos Norte e Leste no Estado de Pernambuco.

The DAA of the Eastern Axis extends through the municipalities of Floresta, Petrolândia, Custódia, Betânia and Sertânia, in Pernambuco. However, as this research corresponds to the places directly affected by the 
PISF, a $5.0 \mathrm{~km}$ buffer was created, starting from the referred axis and, with that, the research area went beyond the limits of Pernambuco, reaching the municipality of Monteiro, in Paraíba.

With an extension of 164.125,44 ha, the study area is located in the semi-arid Northeast and its main types of vegetation are the Wooded Steppe-Savanna and the Forest Steppe-Savanna. It presents average annual rainfall below $800 \mathrm{~mm}$, average sunshine of 2,800 hours per year, average annual temperatures of $23^{\circ} \mathrm{C}$ to $27^{\circ} \mathrm{C}$, evaporation of $2,000 \mathrm{~mm}$ per year and average relative humidity around $50 \%$, which favors the negative water balance (BRITO; MOURA; GAMA, 2007).

\section{Data collection and analysis}

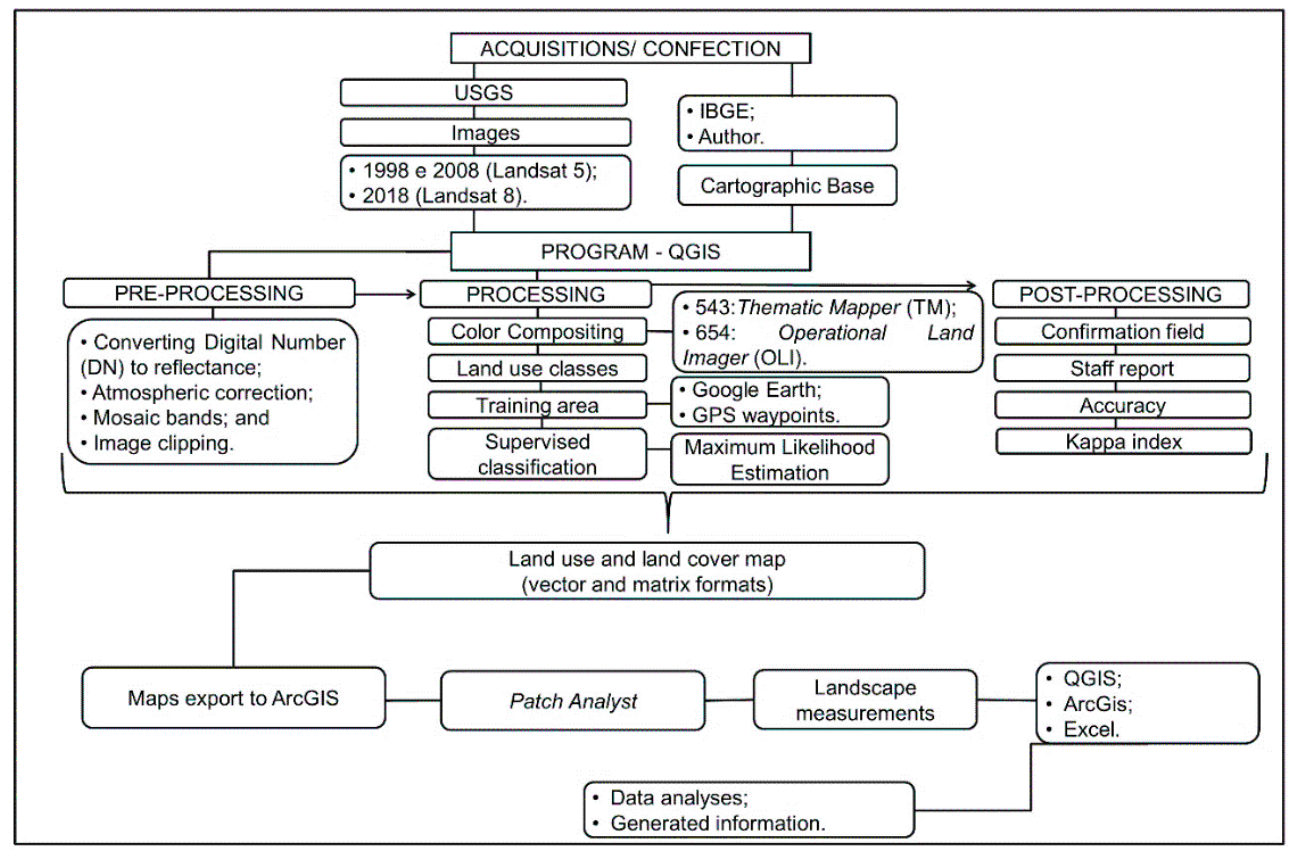

Figure 2. Methodological flowchart for the analysis of land use and land cover and landscape structure in the Eastern Axis of the Directly Affected Areas of the PISF.

Figura 2. Fluxograma metodológico às análises do uso e cobertura da terra e estrutura da paisagem na Área Diretamente Afetada do Eixo Leste do PISF.

\section{Land use and cover in the Eastern Axis of the DAA}

To understand the dynamics of land use and cover in the DAA of the base channel (Eastern Axis) of the PISF, the Landsat 5 Thematic Mapper (TM) and Landsat 8 Operational Land Imager (OLI) satellites were used, requested from the USGS - United States Geological Survey (https://earthexplorer.usgs.gov) platform, referring to the years of 1998, 2008 and 2018, respectively, before, during and after transposition. The orbits/points used to acquire the images were: 215/065; 215/066; and 216/066.

The acquisition periods of the images varied between September and October, as they were the months with the lowest cloud cover, which favored the analysis of the areas under study. However, as the drought months are characterized, the spectral response of the vegetation was not so expressive, which required more attention in the process of collecting spectral samples from the targets, because in the dry months the tree and shrub species stood out from their blades (deciduous).

Before carrying out the supervised classification of the study area, the classes of land use and occupation were determined, as noted below. The choice of classes was made with the aim of verifying how much the transposition of the São Francisco River would interfere in the level of the river, in the amount of vegetation, in the expansion of agricultural, urban and/or exposed soils.

Based on the classes of land use and cover of the Brazilian Institute of Geography and Statistics (2017), the classes used in the categorization of the area under analysis were determined, namely: Steppe-Savanna, Riparian Steppe-Savanna, anthropized and/or uncovered area, water resources and agricultural area.

The supervised classifications of the generated compositions were carried out in the SCP Dock tool of the Semi-Automatic Classification Plugin (SCP), where associations were made among the spectral data obtained by the sensors with the land cover classes. Subsequently, the regions of interest (training areas) were selected for each land cover class identified in the image and polygons were generated over homogeneous areas, overlapping the pixels belonging to the same land cover class (CONGEDO, 2016). 
After that, the image classification was performed using the Maximum Likelihood Classification, which is the most common supervised classification method used with remote sensing image data. The algorithm classifies the entire image by comparing the spectral characteristics of each pixel to the spectral characteristics of the land cover reference classes (RICHARDS; JIA, 2006; CONGEDO, 2016).

To confirm the data collected by the satellites, field visits were made in areas close to the transposition, where there was the collection of GPS waypoints in different artificial structure (highways and masonry Works) and natural structure (water resources, vegetation and exposed soil) and confirmation on-the-spot of the types of targets that have been analyzed.

Regarding the post-processing of the data obtained and resulting from the supervised classification, its precision was performed using the Kappa index, which exposes the performance of the classification and can be qualified based on the following parameters (LANDIS; KOCH; 1977): <0.00 lousy; 0.00-0.20 bad; 0.21-0.40 reasonable; 0.41-0.60 good; 0.61-0.80 very good; and 0.81 - 1.00 great.

With the application of the mathematical operations of the GIS on the maps of the two decades, it was obtained: quantification of areas in hectares, referring to each class of use and coverage in each year; percentage of occupation of the DAA for each class of land use and land cover in all selected years; percentages of variation for the periods 1998-2008, 2008-2018 and 1998-2018 for the DAA (MELLO et al., 2011; MORAES et al., 2017).

Based on the aforementioned authors, the difference in area in hectares was carried out from one date to another (Equation 1), therefore, calculated to verify the increase or decrease in occupation.

$$
\text { Diference }(\text { ha })=\text { Area }_{\text {final date }}-\text { Area }_{\text {start date }}(\text { Equation } 1)
$$

Where: Area $_{\text {final date: }}$ class area in the final year, in ha; and

Area $_{\text {start date: }}$ class area in the initial year, in ha.

The percentage of variation for each period was calculated based on equation 2 .

$$
\text { Variation }(\%)=\frac{\text { Area }_{\text {final date }}-\text { Area }_{\text {start date }} \times 100}{\text { Total Area }}(\text { Equation } 2)
$$

Where: Total area: the entire length of the study area, in ha

\section{Landscape Structure in the Eastern Axis of the DAA}

Regarding the landscape structure, its analysis was initiated by the use of post-classified files (matrix and vector). From the vector data, polygons were selected for the Steppe-Savanna and Riparian Steppe-Savanna classes, which served as the basis for obtaining the metrics of the landscape. As for the determination of metrics, the following were selected (VOLOTÃO, 1998): Class Area (CA); Media Sustainability Index (MSI); Mean Patch Fractal Dimension (MPFD); Number of Patches (NP); Total Edge (TE); Edge Density (DE); Middle Central Area (MCA); and Total Central Area (TCA). The metrics were obtained using the Patch Analyst tool, an extension of ArcGIS 10.5, which provides spatial statistical estimates using vector and matrix files, based on the principles of Landscape Ecology. Regarding the analysis of the central area, a $50 \mathrm{~m}$ negative buffer was applied to calculate the Core Area.

\section{RESULTS}

\section{Land use and cover in the eastern axis of the daa}

The results of the Kappa index for the classifications carried out in 1998, 2008 and 2018 were 0.97, 0.94 and 0.95, respectively, which corresponds to an excellent classification quality (LANDIS; KOCH, 1977). The temporal analysis carried out over the 20-year period (1998 to 2018), which occurred in the Eastern Axis of the DAA of the São Francisco River transposition (Figures 3 and 4), found significant changes in the evaluated environment, as shown in Table 1. 


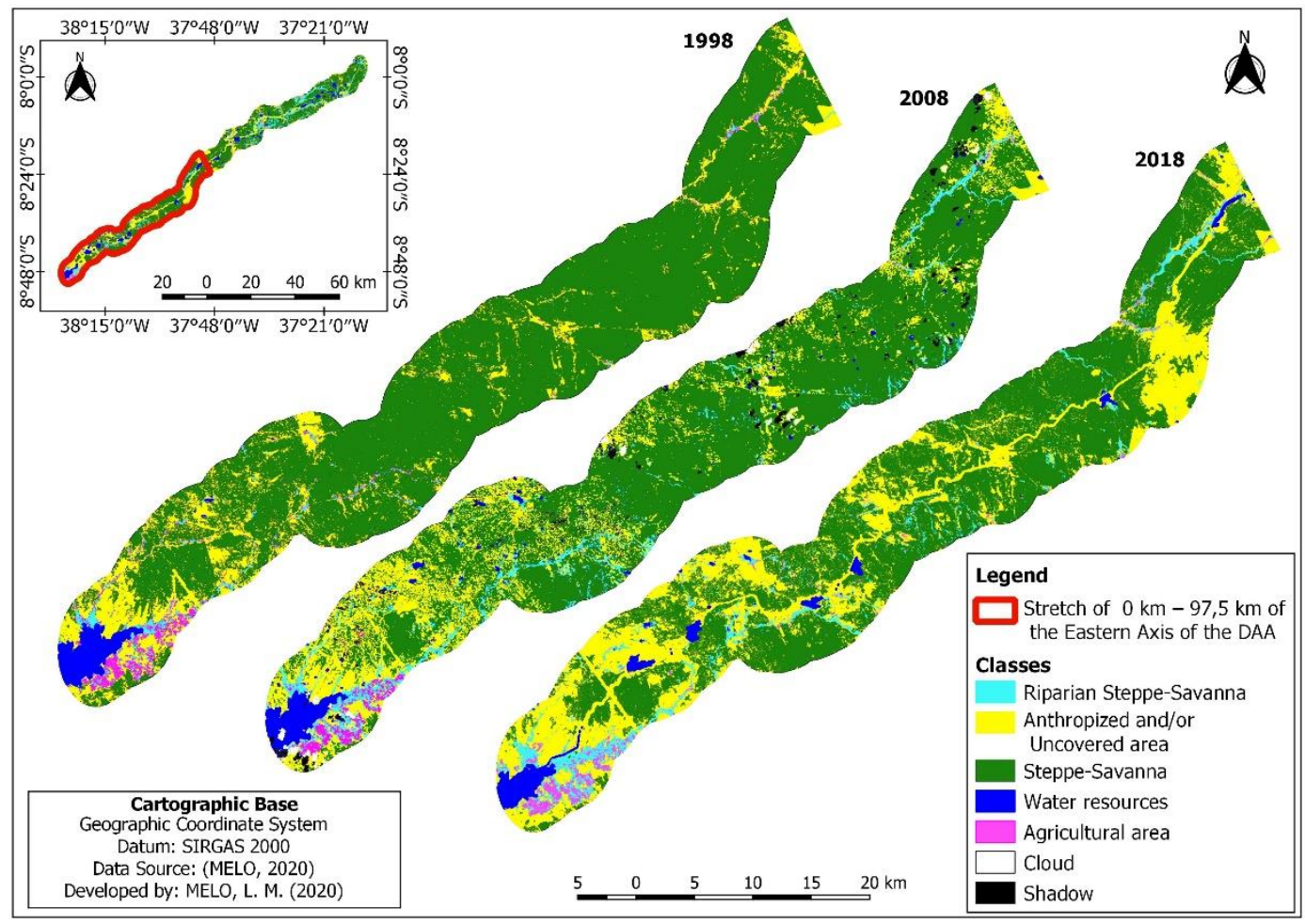

Figure 3. Dynamics of land use and coverage, in the years 1998, 2008 and 2018, in the Directly Affected Area referring to the stretch of $0 \mathrm{~km}-97.5 \mathrm{~km}$ of the East Axis of the PISF.

Figura 3. Dinâmica de uso e cobertura da terra, nos anos de 1998, 2008 e 2018, na Área Diretamente Afetada referente ao trecho de $0 \mathrm{~km}-97,5 \mathrm{~km}$ do Eixo Leste do PISF.

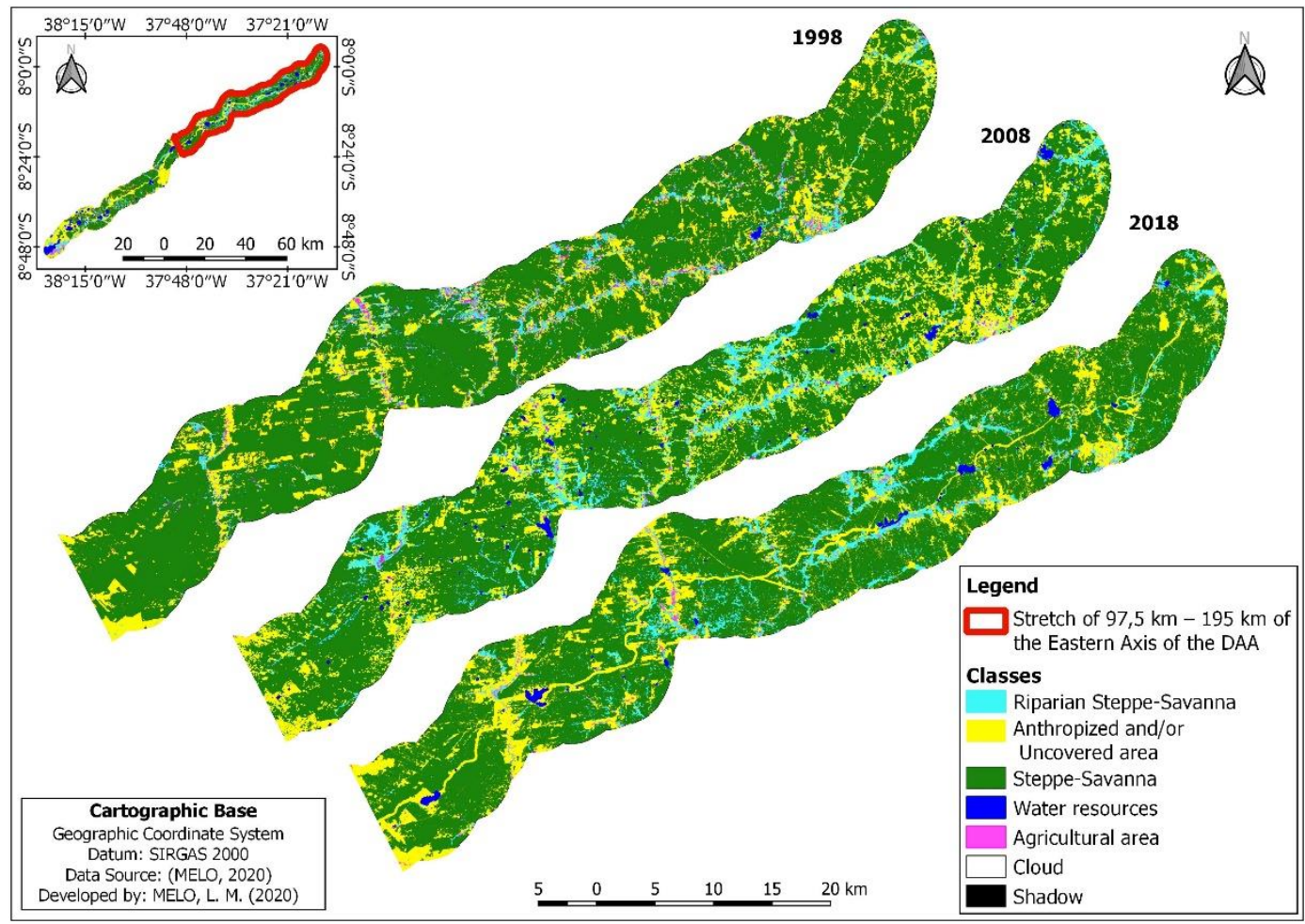

Figure 4. Dynamics of land use and coverage, in the years 1998, 2008 and 2018, in the Directly Affected Area referring to the stretch of $97,5 \mathrm{~km}-195 \mathrm{~km}$ of the Eastern Axis of PISF.

Figura 4. Dinâmica de uso e cobertura da terra, nos anos de 1998, 2008 e 2018, na Área Diretamente Afetada referente ao trecho de 97,5 km - $195 \mathrm{~km}$ do Eixo Leste do PISF.

FLORESTA, Curitiba, PR, v. 51, n. 3, p. 648-657, jul/set 2021. 
Table 1. Areas in hectares (ha) and percentage (\%) of classes of land use and cover in the Eastern Axis of the Directly Affected Area of the PISF.

Tabela 1. Áreas em hectares (ha) e porcentagem (\%) das classes de uso e cobertura do solo na Área Diretamente Afetada no Eixo Leste do PISF.

\begin{tabular}{l|r|r|r|r|rr}
\hline \multirow{2}{*}{ CLASSES } & \multicolumn{2}{c|}{1998} & \multicolumn{2}{c|}{2008} & \multicolumn{2}{c}{2018} \\
\cline { 2 - 7 } & \multicolumn{1}{c|}{ ha } & \multicolumn{1}{c|}{ ha } & \multicolumn{1}{c}{ ha } & \multicolumn{1}{c}{ ha } \\
\hline Steppe-Savanna & $135.035,55$ & 82,28 & $131.402,16$ & 80,06 & $112.281,30$ & 68,41 \\
Riparian Steppe-Savanna & $4.463,55$ & 2,72 & $9.251,55$ & 5,64 & $7.632,81$ & 4,68 \\
Anthropized and / or Uncovered area & $21.804,57$ & 13,29 & $18.807,84$ & 11,46 & $40.690,98$ & 24,79 \\
Agricultural area & $1.236,33$ & 0,75 & 778,05 & 0,47 & $1.748,97$ & 1,04 \\
Water resources & $1.585,44$ & 0,97 & $1.555,38$ & 0,95 & $1.771,38$ & 1,08 \\
Cloud & 0,00 & 0,00 & 781,92 & 0,48 & 0,00 & 0,00 \\
Shadow & 0,00 & 0,00 & 1548,54 & 0,94 & 0,00 & 0,00 \\
\hline Total & $164.125,44$ & 100,00 & $164.125,44$ & 100,00 & $164.125,44$ & 100,00 \\
\hline
\end{tabular}

In addition to the results by year, data were also obtained regarding the variations of each class of land use in the periods from 1998 to 2008, 2008 to 2018 and 1998-2018 (Table 2). In which, the Steppe-Savanna class presented the highest percentage of change in the analyzed intervals.

Table 2. Additions and losses of land use and land cover in the Eastern Axis of the Directly Affected Area, for the periods from 1998 to 2008, 2008 to 2018 and 1998 to 2018.

Tabela 2. Adições e perdas do uso e cobertura do solo na Área Diretamente Afetada do Eixo Leste, do PISF, para os períodos de 1998 a 2008, 2008 a 2018 e 1998 a 2018.

\begin{tabular}{l|rrrrrr}
\hline \multirow{2}{*}{ CLASSES } & \multicolumn{2}{|c|}{$1998-2008$} & \multicolumn{2}{c}{$2008-2018$} & \multicolumn{2}{c}{$1998-2018$} \\
\cline { 2 - 7 } & \multicolumn{4}{c}{ Area } \\
\cline { 2 - 7 } & \multicolumn{1}{c}{ ha } & \multicolumn{1}{c}{ ha } & \multicolumn{1}{c}{ ha } & $\%$ \\
\hline Steppe-Savanna & $-3.633,39$ & $-2,21$ & $-19.120,86$ & $-11,65$ & $-22.754,25$ & $-13,86$ \\
Riparian Steppe- & $4.788,00$ & 2,92 & $-1.618,74$ & $-0,99$ & 3169,26 & 1,93 \\
Savanna & $-2.996,73$ & $-1,83$ & $21.883,14$ & 13,33 & $18.886,41$ & 11,51 \\
Anthropized area & $-458,28$ & $-0,28$ & 970,92 & 0,59 & 512,64 & 0,31 \\
Agricultural area & $-30,06$ & $-0,02$ & 216,00 & 0,13 & 185,94 & 0,11 \\
Water resources & 781,92 & 0,48 & $-781,92$ & $-0,48$ & 0,00 & 0,00 \\
Cloud & $1.548,54$ & 0,94 & $-1.548,54$ & $-0,94$ & 0,00 & 0,00 \\
Shadow & & & &
\end{tabular}

\section{Landscape structure in the Eastern Axis of the ADA}

Continuing the spatial analysis of the landscape, the results contained in Table 3 were obtained, referring to the metrics in their different categories.

Table 3. Values of the metrics referring to the classes of vegetation, Steppe-Savanna and Riparian Steppe-Savanna, in the Eastern Axis of the Directly Affected Areas of the PISF, for the years 1998, 2008 and 2018.

Tabela 3. Valores das métricas referentes às classes de vegetação, savana-estépica e savana-estépica ciliar, na Área Diretamente Afetada do Eixo Leste, do PISF, para os anos de 1998, 2008 e 2018.

\begin{tabular}{|c|c|c|c|c|c|c|c|c|c|}
\hline \multirow{2}{*}{ Year } & \multirow{2}{*}{ Classes } & \multicolumn{2}{|c|}{ Shape } & \multicolumn{2}{|l|}{ Edge } & \multirow{2}{*}{$\begin{array}{l}\text { Patches } \\
\text { NP }\end{array}$} & \multirow{2}{*}{ Area } & \multicolumn{2}{|c|}{ Central Area } \\
\hline & & MSI & MPFD & $\mathrm{TE}$ & ED & & & $\mathrm{NCA}$ & TCA \\
\hline \multirow{2}{*}{1998} & SE & 1,27 & 1,40 & $8.857 .980,00$ & 63,50 & 7637,00 & $135.035,00$ & $1.757,00$ & $100.295,00$ \\
\hline & SEC & 1,26 & 1,40 & $2.896 .140,00$ & 20,76 & $11.456,00$ & 4463,55 & 208,00 & 157,77 \\
\hline \multirow{2}{*}{2008} & SE & 1,28 & 1,40 & $11.570 .300,00$ & 82,26 & 6974,00 & $131.402,00$ & $3.502,00$ & $83.197,20$ \\
\hline & SEC & 1,28 & 1,40 & $4.804 .380,00$ & 34,16 & $14.887,00$ & 9251,55 & 849,00 & 471,16 \\
\hline \multirow{2}{*}{2018} & SE & 1,30 & 1,40 & $15.672 .600,00$ & 130,70 & $16.169,00$ & $112.281,00$ & $3.171,00$ & $57.355,90$ \\
\hline & SEC & 1,29 & 1,40 & $3.938 .640,00$ & 32,85 & $12.067,00$ & 7632,81 & 650,00 & 435,53 \\
\hline
\end{tabular}

Where: Classes: SS - Steppe-Savanna; and RSS- Riparian Steppe-Savanna. Metrics: MSI = Mean Shape Index; MPFD = Mean Patch Fractal Dimension; TE = Total Edge ED = Edge Density; NP = Numbers of Patches; $\mathrm{CA}=$ Class Area; NCA - Number of Central Areas; and TCA Total Central Area.

Em que: Classes: SE - Savana-estépica; SEC- Savana-estépica ciliar. Métricas: MSI - Índice de Forma Médio; FRAC - Dimensão Fractal; TE

- Total de Bordas; ED: Densidade de Bordas; NP - Número de Fragmentos; CA - Área da Classe (ha); NCA - Número de Áreas Centrais;

TCA - Área Central Total. 


\section{DISCUSSION}

\section{Land use and land cover in the Eastern Axis of the DAA}

With the reduction of the water resources areas, agriculture area and anthropized area in the studied place, the riparian forest took over the available spaces, which favored the increase of the area of this class in 2008. In 1998, this type of vegetation was not so expressive, as it was a year of severe drought (GUTIÉRREZ, 2014), where rainfall was scarce and variable, with accumulated annual values of 100 and $300 \mathrm{~mm}$. Through the visual interpretation of the classified images, it was observed that, in 2008, the drainage areas, that were previously dry due to drought and that were classified as areas uncovered in 1998, presented riparian forest. Another important point to highlight is the fact that the PISF has already foreseen the removal of $127 \mathrm{~m}^{3} . \mathrm{s}^{-1}$ of water downstream from Sobradinho, in a period when the demand for energy in the Northeast required, among the months of April 2007 and January 2008, that $90 \%$ of the water reserve capacity in Sobradinho be consumed, favoring the reduction of water resources in the environment (MACHADO, 2008). As for the reduction of the Steppe-Savanna areas, on the other hand, it contributed to the beginning of the transposition works in 2007. It should also be noted that there was a reduction in some areas of the classes due to the existence of clouds and shadows covering the area under analysis. The presence of clouds in the images is a factor that interferes in the analysis of the targets, as it prevents the capture, by the sensors of the satellites, of the spectral data referring to the objects under study.

In the period 2008 to 2018, it was the time of greatest intensity of the São Francisco River transposition works, where natural areas were replaced by artificial structures such as channels, reservoirs and pumping stations, in addition to opening up areas for temporary buildings, such as construction sites, lodgings for the workers and access routes for vehicles and machines. As a result, there was a reduction of $11.65 \%$ in the Steppe-Savanna areas and an increase of $13.33 \%$ in the anthropized and/or uncovered area.

Another significant impact in this period is associated with the reduction of riparian forest, which affected the fundamental element for the control of erosion on the banks of water bodies and to minimize the effects of possible floods. This type of vegetation is essential for environmental balance, in addition to maintaining the quantity and quality of water, as it works as a natural filter for possible residues of chemical products such as pesticides and fertilizers, in addition to representing an important habitat for fauna. In the case of the São Francisco River, it is estimated that $96 \%$ of the riparian forests on its river banks have already been destroyed (ZELLHUBER; SIQUEIRA, 2016). The $0.13 \%$ increase in water resources was due to the expansion of artificial water reservoirs, such as the Mandantes and Salgueiro reservoirs.

In the last period, 1998-2018, there was a reduction of $22.754,25$ ha (13.86\%) of Steppe-Savanna vegetation in the DAA. Among the reasons for deforestation are the works on the Eastern Axis of the transposition, which cover approximately $195 \mathrm{~km}$ of infrastructure. The Environmental Impact Report (RIMA) of this project already predicted loss and fragmentation estimated at 430 ha of areas with native vegetation and terrestrial fauna habitats for the axes (BRASIL, 2004), however, this is surpassed as seen above. As for anthropized and/or uncovered areas, there was an increase of 18.886,41 ha, which were expanded as a result of the aforementioned works and the expansion of urban areas.

In addition, supposedly, there is a suppression of vegetation for extractive purposes from the exploitation of the Caatinga through the sale of firewood and/or charcoal and the implantation of areas for agriculture, which often occur unsustainably, from an environmental point of view. Therefore, potentiating the impacts on the biotic and abiotic resources of the environment. Regarding the increase in the area of the Riparian Steppe-Savanna, of $1.93 \%$, in the period 1998-2018, the same was noticeable, since there was a dry period in 1998, which disadvantaged the development of vegetation, already in later years, as seen in this classification, it became more expressive, increasing its area.

Water resources were increased by $0.11 \%$, as there was an increase in the number of artificial water reservoirs, including the transposition channel itself. The agricultural area, on the other hand, grew $0.31 \%$, surpassing the 1998 period, which suffered from the drought. Another aspect that facilitated the growth of these areas was the viability of irrigated agriculture, being an attraction for rural producers.

The increase in water resources and agricultural areas are positive points for the socioeconomic aspects, as they contribute to the generation of work and income for people affected by the climatic vicissitudes of the semi-arid region. However, there is a reduction in forest areas and an increase in exposed soil environments, when there are no sustainable practices in the management of areas.

Regarding the increase in anthropized areas, Silva and Silva (2015) explain that the transposition of the São Francisco River has contributed to the increase of this type of areas and that, due to deforestation, it can generate serious environmental problems for the semi-arid Northeast, in addition to the existing ones due to the fragmentation and physical barrier generated with the construction of the channel. With the suppression of local vegetation, there are also the loss of the topsoil of the soil; increased dust emissions; silting of water bodies; soil 
salinization due to the marginal use of water along the channel by farmers and the consequent increase in areas potentially susceptible to the desertification process.

According to Siqueira Filho et al. (2012), it was found that plant biodiversity in the stretches that comprise the Northern and Eastern Axes of the São Francisco River was composed of 1,031 flora taxa, of which 136 were endemic (13\%), six threatened with extinction and 28 candidates to enter the list of endangered species in Brazil.

With the reduction of vegetation in the Caatinga, there are also impacts on pollinating species, as, by changing ecosystems that have great potential for all locally adapted bees, the availability of resources necessary for the reproductive increase and maintenance of these invertebrates is affected, such as: resins, perfumes, pollens, nectaries, oils and nesting sites, fundamental resources for the good development of colonies and individuals. As a way of mitigating the exposed, measures must be taken to minimize anthropic actions that degrade the main Northeastern Phytogeographic domain (BRASIL; GUIMARÃES-BRASIL, 2018).

The increase in water resources and agricultural areas are positive points for socioeconomic aspects, as they contribute to the generation of jobs and income for people affected by climatic events in the semi-arid region. However, there is a reduction in forest areas and an increase in exposed soil environments, when there are no sustainable practices in the management of the areas. In addition to the impacts of the PISF on vegetation, the vegetation suppression of the Caatinga basically takes three forms: legal deforestation, authorized by Organs competent bodies, for purposes of alternative land use (agriculture, pasture); sustainable forest management, authorized by Organs competent bodies, for the purposes of timber production; or illegal deforestation, for energy purposes, exploration of non-timber products, among other factors (PAREYN, 2010).

\section{Landscape structure in the Eastern Axis of the ADA}

Through the metrics MSI and MPFD, changes in the shape of the fragments were observed. The MSI metric indicates how close the fragment is to a circumference, which will have a minimum value equal to 1 . For the Steppe-Savanna, the values of this metric varied from 1.27-1.29 and for the Riparian Steppe-Savanna it ranged from 1.26-1.29, over the period of 20 years. These types of classes, over the years, gradually acquired characteristics of irregular shapes of fragments, even if in a minimal way. In addition, it appears that there was an increase in the number of forest fragments and a reduction in the areas of the classes, generating an increase in the values of TE and DE.

Due to the sensitivity to local climatic changes, the Caatinga vegetation showed less expressiveness in 1998, which contributed to variations in the shapes of the fragments in later years, which cause greater rainfall (as explained above). In this context, care was taken in the choice of images, in order to select scenes belonging to the same climatic period. In this case, the drought period was selected, which favored the choice of images with less cloud cover. The Riparian Steppe-Savanna showed an increase in its areas from 1998-2008, which did not cause an approximation of 1 in the MSI, but a distance, showing that the fragments tended to irregularity. One of the signs that contributed to this was the increase of humid areas in 2008, compared to 1998. One point must be emphasized, that it is not only the fragmentation that will affect the irregularity of the fragment's shape, but also its increase in area. In 2018, there was a reduction in the fragments, also there was an increase in the MSI values and an increase in the TE and DE values, which, consequently, contributed to the edge effect.

With the increasing fragmentation of the area, there was an increase in the edge areas of the habitat, which is related to the impacts of the edge effects. This fact is related to the shape of the fragment, the larger the border, the more irregular the shape, which is directly linked to the relationship between the perimeter and the area; the smaller this relation, the smaller the border will also be and vice versa, fragments of more regular shapes will have the border-area relationship minimized and, therefore, the center of the area will be further from the edges. Therefore, a central area is separated from external factors, while fragments of more irregular shapes have a higher proportion of edges, causing greater interaction with a matrix to occur, which, over time, will lead to the quality of the structure of ecosystems (PIROVANI et al., 2014).

As for the analysis of central areas, in the period 1998-2008, there is an increase in the number of central areas, but a reduction in the value of the total central area (in hectares) in the Steppe-Savanna, which can be explained by the advance of anthropic activity in the region, causing increasing fragmentation, which is reflected in the higher values of DE and TE. Regarding the Riparian Steppe-Savanna, it presented increases in the NCA and TCA, which is a reflection of the territorial expansion of this vegetation in this period. In 2018 , this vegetation again loses its proportion of area, which favors the reduction of the aforementioned metrics. The favoring of this is related to the increase in forest fragmentation which, consequently, contributes to the added edge effect and to the reduction of the central area of the fragments, negatively influencing the quality of the ecosystem structure (HENTZ, 2015).

Within the studied area, it was found that, over the 20 years, there was an increase in forest fragmentation, corroborating the results referring to the metrics of the central area, which demonstrate that, with the reduction of the fragment size, there is a trend of loss from the center area due to the edge effect. As a result of these facts, there 
is a need for greater attention in the ADA of PISF, in order to set goals aimed at forest connectivity, its management and conservation of biodiversity.

\section{CONCLUSION}

- Through this study, a lower change in the landscape was verified in the period before PISF and a higher rate of change due to the implementation of the Project;

- $\quad$ During the period 1998-2018, the vegetation cover of Steppe-Savanna decreased by $13.86 \%$. However, there were increases in the areas of Riparian Steppe-Savanna, Water resouces, Agricutural and Anthropized and/ or discovered in $1.93 \%, 0.11 \%, 0.31 \%$ and $11.51 \%$, respectively; and

- Large-scale construction facilities favor forest fragmentation and the edge effect, which contributes negatively to central áreas.

\section{ACKNOWLEDGEMENTS}

To the Brazilian Federal Agency for Support and Evaluation of Graduate Education (CAPES), for the financial support, and to the Post-Graduate Program in Forest Sciences, of the Federal Rural University of Pernambuco (UFRPE), for the technical and professional support.

\section{REFERENCES}

BRASIL, D. F.; GUIMARÃES-BRASIL, M. O. Principais recursos florais para as abelhas da caatinga. Scientia Agraria Paranaensis, Marechal Cândido Rondon, v. 17, n. 2, abr./jun., p. 149-156, 2018.

BRASIL. Ministério da Integração Nacional. Relatório de Impacto sobre o Meio Ambiente do Projeto de Integração do Rio São Francisco com Bacias Hidrográficas do Nordeste Setentrional. Brasília: Ministério da Integração Nacional, 2004.

BRITO, L.T. de L.; MOURA, M.S.B. de; GAMA, G.F.B. Potencialidades da água de chuva no Semi-árido brasileiro. Petrolina: Embrapa Semi-Árido, 2007. 181p.

CONGEDO, L. Semi-automatic classification plugin documentation. Release, v. 4, n. 0.1, p. 29, 2016.

CNUC - Cadastro Nacional de Unidade de Conservação do Ministério do Meio Ambiente. Unidades de Conservação (2019). Disponível em:< https://www.mma.gov.br/areas-protegidas/cadastro-nacional-de-ucs $>$ Acesso em: 16 set. 2020.

GUTIÉRREZ, A. P. A.; ENGLE, N. L.; NYS, E.; MOLEJÓN, C.; MARTINS, E. S. Drought preparedness in Brazil. Weather and Climate Extremes, Liverpool - UK, v. 3, p. 95-106, jun. 2014.

HENTZ, A.; CORTE, A.; DOUBRAWA, B.; SANQUETTA, C. R. Avaliação da fragmentação dos remanescentes florestais da Bacia hidrográfica do rio Iguaçu-PR, Brasil. Enciclopédia Biosfera, Goiânia, v. 11, n. 21, p. 28422858, jun. 2015.

IBGE - Instituto Brasileiro de Geografia e Estatística. Monitoramento da cobertura e uso da terra do Brasil 2000 - 2010 - 2012 - 2014. IBGE: Rio de Janeiro, 2017.

LANDIS, J. R.; KOCH, G. G. The measurement of observer agreement for categorical data. Biometrics, Washington, v. 33, n. 1, p. 159-174, mar. 1977.

LARIS, P.; JO, A.; WECHSLER, S. P. Effects of landscape pattern and vegetation type on the fire regime of a mesic savanna in Mali. Journal of environmental management, [S.1.], v. 227, p. 134-145, dec. 2018.

MACHADO, A. T. M. A construção de um programa de revitalização na bacia do Rio São Francisco. Estudos avançados, São Paulo, v. 22, n. 63, p. 195-210, jan. 2008.

MELLO, K.; TOPPA, R. H.; ABESSA, D. M. Dinâmica da paisagem do município de Cubatão: crescimento entre portos, indústrias e a Serra do Mar. O Mundo da Saúde, São Paulo, v. 35, n., 142-46, jan. 2011.

MORAES, M. C. P.; MELLO, K.; TOPPA, R. H. Protected areas and agricultural expansion: Biodiversity conservation versus economic growth in the Southeast of Brazil. Journal of environmental management, [S. 1.], v. 188 , p. 73-84, mar. 2017. 
PAREYN, F. G. C. Gestão no Estado de Pernambuco - O papel do manejo florestal sustentável. In: GARIGLIO, M.A.; SAMPAIO, E.V.S.B.; CESTARO, L.A.; KAGEYAMA, P.Y. Uso sustentável e conservação dos recursos florestais da Caatinga. Brasília: Serviço Florestal Brasileiro, 2010.

PIROVANI, D. B.; SILVA, A. G. D.; SANTOS, A. R. D.; CECÍlIO, R. A.; GLERIANI, J. M.; MARTINS, S. V. Análise espacial de fragmentos florestais na Bacia do Rio Itapemirim, ES. Rev. Árvore, Viçosa, v. 38, n. 2, p. 271-281, abr. 2014.

QUEIROZ, L. P.; CARDOSO, D.; FERNANDES, M. F.; MORO, M. F. Diversity and Evolution of Flowering Plants of the Caatinga Domain. In: Silva JMC, Leal I, TABARELLI, M. Caatinga: the largest tropical dry forest region in South America. Cham: Springer, 2017.

RICHARDS, J. A.; JIA, X. Remote Sensing Digital Image Analysis: An Introduction. Berlin, Germany: Springer, 2006.

SANTOS, A. R. et al. Geotechnology and landscape ecology applied to the selection of potential forest fragments for seed harvesting. Journal of environmental management, [S.1.], v. 183, p. 1050-1063, dec. 2016.

SEDDON, A. W. R.; MACIAS-FAURIA, M.; LONG, P.R; BENZ, D.; WILLIS, K. J. Sensitivity of global terrestrial ecosystems to climate variability. Nature, [S.1.], v. 531, p. 229-232, feb. 2016.

SILVA, A. C.; SOUZA, A. F. Aridity drives plant biogeographical sub regions in the Caatinga, the largest tropical dry forest and woodland block in South America. PLoS One, [S.1.], v. 13, p. e0196130, abr. 2018.

SILVA, A. K. O.; SILVA, H. P. B. O processo de desertificação e seus impactos sobre os recursos naturais e sociais no município de Cabrobó-Pernambuco-Brasil. PRACS: Revista Eletrônica de Humanidades do Curso de Ciências Sociais da UNIFAP, Macapá, v. 8, n. 1, p. 203-215, jan./jun. 2015.

SIQUEIRA FILHO, J.A.; SOUZA, D.P.; SIQUEIRA, A.A.; MEIADO, M.V.; CORREA, L.C.; CAMPELO,M.J.A.; RAMOS,R.R.D. A queda do mito: Composição, Riqueza e Conservação das plantas vasculares das Caatingas do Rio São Francisco. SIQUEIRA FILHO, J. A. In: Flora das Caatingas do Rio São Francisco: História Natural e conservação. 1. ed. Rio de Janeiro: Andrea Jakobsson Estúdio Editorial, 2012.

VOLOTÃO, C. F. S. Trabalho de análise espacial: métricas do Fragstats. São José dos Campos: INPE, p. 45, 1998.

ZELLHUBER, A; SIQUEIRA, R. Rio São Francisco em descaminho: degradação e revitalização. Cadernos do CEAS: Revista crítica de humanidades, Salvador, n. 227, p. 3-24, jul./set. 2007

WU, J. Landscape Ecology. In: LEEMANS, R. Ecological Systems. New York: Springer, 2013. 